\title{
Readiness Of Community Learning Center in The ASEAN Economic Community Era
}

\author{
Rivo Nugroho \\ Program Studi Pendidikan Non Formal, \\ Fakultas Ilmu Pendidikan, Universitas Negeri Surabaya \\ Surabaya, Indonesia \\ rivonugroho@unesa.ac.id
}

\author{
Indrawati Theresia, Widya Nusantara \\ Program Studi Pendidikan Non Formal, \\ Fakultas Ilmu Pendidikan, Universitas Negeri Surabaya \\ Surabaya, Indonesia
}

\begin{abstract}
The era of the ASEAN economic community as if become scary for the people of Indonesia, in the center of the weak competitiveness of local, the weak the protection the state of the sector local (economics, industry, and education) skeptically capable of grated local potentials main education sector lack in various resources. In this research will examine some things pertaining readiness public learning activity center on the existence of the community economic Asia. In addition, also public learning activity center as education center non-formal managed directly by the public learning activity center play an important role and as a forum to make the citizens smart. The purpose of this study is to find readiness community learning center in the ASEAN economic community that in terms of the planning aspect and implementation of programs that are carried out by community learning center.
\end{abstract}

Keywords : Community Learning Center (CLC), ASEAN Economic Community (AEC).

\section{INTRODUCTION}

Indonesia is now the middle of the race against time in welcoming the execution of free markets of Southeast Asia, or commonly referred to with the ASEAN Economic Community (AEC) began in the year 2015. ASEAN has agreed on priority sectors toward the moment. When the ASEAN Summit took place the 9th year 2003 designated 11 Priority Integration Sectors (PIS). But in 2006 the PIS assigned evolved into 12 which are divided in two parts, namely industrial goods sector seven and five services sectors. The 7 th sector goods industries consists of agriculture, electronic-based products, rubber-based products, fisheries, textiles, automotive, and wood-based products. While the services sector is the fifth air transport, easean, health services, logistics services and tourism [1].

Indonesia's chances of being able to compete in the ASEAN Economic Community (AEC) are actually quite large. Currently, Indonesia is ranked 16th in the world for the magnitude of economies of scale. The magnitude of economies of scale is also supported by the proportion of the population age and productive middle-class growth. In 2011, the Government has devised a series of programs as an integral part of national development based on the regulations of the President of the Republic of Indonesia Number 32 Year 2011 about Masterplan Acceleration and expansion of the economic development of Indonesia 2011-2025. All series of programs and activities the development becomes less meaningful when less government understand the world Investment Report vicious circle prospective destinations that become an obstacle to national development. One such obstacle is infrastructure development constraints. The Government has not succeeded in development of infrastructure such as the construction of infrastructure for the integrated mass transport and transport infrastructure are generally for the entire territory of Indonesia. The failure of the infrastructure development impact on the weak competitiveness of Indonesia's products in foreign countries.

On the other hand, in the rating of the World Economic Forum (WEF), the competitiveness of Indonesia suffered a big leap from rank 50 be 38 . This rating is the leap of great achievement for Indonesia, and only surpassed by Ecuador and Lesotho. However, Indonesia's ranking jumps the new approach the ratings of other ASEAN countries, especially Singapore, Malaysia, Thailand, and Brunei Darussalam. This triggered a big question, namely whether Indonesia was ready to face the ASEAN Economic Community (Kemenkeu, 2014).

In the face of the implementation of the AEC 2015, Indonesia still faces some challenges both external as well as internal. The external challenges faced by, among others, is the level of competition is getting tougher trade, the magnitude of the trade balance deficit in Indonesia with other ASEAN countries, Indonesia is and how it can enhance the attractiveness of the investment. Meanwhile, Indonesia's internal challenges, among others, is the low level of understanding of the people against the AEC, unpreparedness area facing the AEC, the level of regional development that still vary widely and the conditions of employment and HUMAN RESOURCES Indonesia. In addition to the existing challenges, Indonesia still has a great opportunity to be able to benefit from the implementation of the AEC for the welfare of society Indonesia. Until recently, Indonesia remains the investment goals of investors in the country or abroad. The high investment costs have been encouraging economic growth is relatively high compared to other ASEAN countries [2]

The implementation of the ASEAN economic community resulted in a decrease in the cost price of the import-export into $0-5$ percent and the abolition of quantitative restrictions and other non-tariff barriers. Opening of the halls of the lowliest of the ASEAN free trade predicted being able to encourage positive things for the economic development of Indonesia, 
first, pushing the State revenue through export and import. Second, open the new industrialization opportunities in the area of Indonesia was lethargic due to the monetary crisis which occurred in 1998. Third, expanding the employment of professionals for the explosion of a new generation of young generations in Indonesia and provide career opportunities in various areas in ASEAN. But at the same time, concerns against the market economy is also becoming a scary Specter for entrepreneurs, Indonesia amid the weak competitiveness of local industry, the weakness of State protection against the feared local industries able to erode the potential of local entrepreneurs and small and medium businesses which still lack in various aspects of the economy. In addition to this economically, Indonesia was no better than Singapore, Malaysia, Thailand and Cambodia. But the failure of the old market economy has opened up a free market in a new way of looking the market economy was built on the authorization of the State. The State guarantees a wide range of facilities and infrastructure supporting the sustainability of markets, such as financial stability, domestic security, and law enforcement. When needed, so the country can also use its power so that the market can run and function properly. Furthermore, when there is no market in the area who need a utility such as land, water, electricity, education, health services, and social security. Then the State should provide the market, because in view of the new market economy, the role of the State will be reduced gradually and proportionally to create stability in the market, so that the role of the State is not lost as understood by conventionally understand the market economy, but the market economy remains wedded to the principle of free competition that requires all parties to concentrate on quality and speed in reading the market tendencies and simultaneously giving protection to countries that support in a positive market dynamics. Free-market political AEC which have been enacted in 2015 is able to provide positive and negative for the economic development of Indonesia and its influence for the expansion of industrialization and new business-business opportunities for the development of Indonesia [3]

Role of non-formal Education other than as part of the education system has a very important role in the framework of the development and implementation of lifelong learning (lifelong learning) [4]. Discuss the non-formal education does not mean only discusses the non-formal education as an alternative to the society, but talk of non-formal education is talking about the concept, theory and educational norms intact in accordance with the conditions and the needs of the life of the community. Non-formal education is an educational service that is not restricted by time, age, sex, race (the tribe, descendants of) social conditions, culture, economy, and religion. Mentioned the community learning activities Center (CLC) is a model of the institutionalization of education community professionally managed by nongovernmental organizations or other community organizations, so that people can easily relate to the activity center learning society and request information about various community education programs. Be clear here that the function activity center learning community is to educate the public through a wide variety of things [4]. The condition of the community and learning activities center in the Asian economic community must be able to accommodate all the interests and the needs of society in the era of connectedness and freedom of access economics on the scope of Asia.

There are three important goals in the development of community learning centers that is (a) empowering communities to be self-sufficient (powerless), (b) improve the quality of life of the community both in terms of social as well as economic, (c) increase the sensitivity to the problems that occur in their environment so that it is able to solve these problems the purpose of the development center of learning activities such as the community demands that the center of the community and learning activities should now be adaptive towards any changes there [4].

If we examine the AEC maybe we will only be focused on sectors that are not directly related to education such as the flow of goods, labor and competition of other things that smelled of the economy. There is one important sector that we need to review that is education. Education is meant here is the non-formal education are by Community Learning Center (CLC) or often referred to community learning activities Center (CLC). Describes the growth of community and learning activities center PKBM still are quantity, not coupled with quality. Low quality management of Community Learning Center caused by three things: the quality of inputs, the quality of the process and the quality of the output. From the observations demonstrate the management of community learning center programs is considered quite good, but the purpose of the development-oriented Community Learning Center economic aspects (employment and income) is not reached with both. Shove off from this condition, the analysis needs to be done with regard to the readiness of the Community Learning Center during the ASEAN economic community currently in particular in the field of education [5].

\section{METHOD}

This type of research is qualitative research. Data source derived from the citizens learn, tutors and organizers of the community learning activities center. The data was processed using the research results a descriptive qualitative approach. The collection of data in this study using method (1) interview (2) observation (3) documentation. Technique of data analysis is performed by means of (1) data Reduction (2) presentation of data (3) withdrawal of the conclusion. The focus of this study is to describe and analyze the readiness Center for community learning activities in the ASEAN economic community. Especially in the aspects of planning and execution.

\section{RESULTS AND DISCUSSION}

Data analysis was performed of the results of the collection of data through observation, interviews, and documentation. This research describes about program planning and program implementation in the activity center learning community. Non-formal education activities of studying and trying to integrate in the fields of industry, trade and services according to the needs of learners and the learning resources available in their environment, which basically has touched an effort of coaching development and entrepreneurship [6]. Entrepreneurship is essential for the process of empowerment 
(empowering process) society in economics related to the field of social, cultural, political, and so on.

\section{A. Program planning of Community Learning Center (CLC)}

Program planning is required to know the potential of the communities and the surrounding environment. One of the aspects in the planning i.e. do a needs analysis (need assessment). The purpose of the analysis of training needs is to find or identify what skills needed by students in order to support the needs of life. This can be identified if the post training going positive changes that can support the better performance. In addition to providing assurance on the quality of individual or organization scalable performance through the training certificate provided [7]. These changes not only in the form of change of knowledge but a change in attitude. Dale S. Beach [4] posited, "the objective of training is to achieve change in the behavior of those trained".

Training in General was improving the ability in terms of expertise/technical ability (skill Competency) and selfdevelopment abilities (soft skill Competency). This must be something that is desperately needed by individuals, to provide confidence in the competence. [4].

In the planning of programs that will be used in the implementation of the training and education required learning assignment methods. The methods used in the implementation of learning among other methods of lecture, discussion, case study, practice, and motivation. Participants get involved directly through the method used because it is expected of the participants can be active in a given learning acknowledge. The composition used in the implementation of learning is a theory and practice. Explained that "training typically involves instruction and practice aimed at reaching a particular level of competence or operative efficiency as a result of training, we are able to respond adequately and appropriately to some expected and typical situation". The use of theory and practice is used proportionately according to the needs [8].

\section{B. Program implementation in Community Learning Center}

On aspects of the implementation of the program in the Centre of the activities of learning society aims to increase interest in learning the learners in the learning process in the classroom, tutor trying to motivate learning to learners. In its execution to the tutor approach using andragogy learners in delivering material by delivering an experience beyond the classroom into the subjects especially in material accordance with everyday life, so that the material can be easily understood by the learners so that learners can play an active role in following the process of learning, either ask or answer a question posed by a tutor, in addition the learners can also share experiences to friends and tutors are related with the material he had learned.

Effort to increase interest in learning to learners in these last three months, not just equality program tutor who apply the andragogy approach but the tutors of literacy programs and others are also implemented the andragogy approach with the objective to help increase interest in learning to learners, so current students already accustomed to following the material in ways that centered on issues based on experience.
Tutors tend to take the andragogy approach is basically due to the background of the students is no longer the equivalent of a dozen years old students of the same age range with a formal, but they range over 17 years of age and his status also varies. So that in carrying out the learning process, learners is not easy to accept the material to the maximum, because they also already have respective private interests, be it the interests of family and work. In accordance with the said Skinner [9] Andragogy stated that, learning from the experience of the good that comes from the outside or inside a person, but the man is free to choose his experience as the environment provide a reaction to his thoughts and his feelings. The behavior is seen as aims, react to internalize the experience in relation to basic human needs and the needs of the environment.

Approach to adult or commonly known with the approach of andragogy model is learning that in applying the material is associated on the basis of the experience of either personal experience as well as others, because as you get older then it is also increasing the experience and insight into his thinking, so learners will more easily understand the material presented by the tutor.

\section{CONCLUSION}

Based on the results of the research conducted, it can be obtained a summary regarding the readiness of a Community Learning Center in the face of ASEAN Economic Community in view from the aspect of planning and program implementation. The readiness of the community and learning activities center in the ASEAN Economic Community is still not optimal. Many types of non-formal education program which actually can still be further developed to meet the needs of the learning community. Each individual as learners have characteristics and its own learning needs. Therefore, the first step must be done in a Community Learning Center to develop programs that are oriented in the ASEAN economic community was been indicted for the identification of the needs of the learning community. Based on the results of the identification can be determined precisely and systematically a variety of non-formal education program. Series of activities related to the development of various types of the non-formal education program in the framework of the ASEAN economic community is facing can be optimized through cooperation between companies, agency, and related stakeholders, with this good cooperation, community around the central region community learning activities will benefit much more optimal.

\section{REFERENCES}

[1] H. Wangke, "Peluang Indonesia dalam masyarakat ekonomi Asean 2015," Info Singk. Hub. Int., vol. 6, no. 10, pp. 5-8, 2014.

[2] P. Riset Kajian, "Analisa Daya Saing dan Produktivitas Indonesia Menghadapi AEC.” Jakarta: PKRB-BKF, 2014.

[3] A. AbduRofiq, "Menakar pengaruh masyarakat ekonomi ASEAN 2015 terhadap pembangunan Indonesia," SALAM J. Sos. dan Budaya Syar-i, vol. 1 , no. 2,2014 . 
[4] M. Kamil and Riduwan, Pendidikan nonformal: pengembangan melalui pusat kegiatan belajar mengajar (PKBM) di Indonesia: sebuah pembelajaran dari kominkan di Jepang. Alfabeta, 2009.

[5] U. Suminar, "Hubungan Kemampuan Manajerial, Motivasi Kerja, dan Persepsi Pengelola terhadap Program Pemberdayaan dengan Mutu Pelayanan PKBM di Kabupaten Garu." Bandung: Tesis Program Pascasarjana Pendidikan Luar Sekolah. Universitas Pendidikan Indonesia, 2005.

[6] D. Sudjana, "Pendidikan Nonformal: Wawasan, Sejarah Perkembangan, Filsafat \& Teori Pendukung, serta Asas," Bandung Falah Prod., 2004.

[7] S. Notoatmodjo, Pengembangan sumber daya manusia. Rineka Cipta, 1992.

[8] M. Tight, "Key Concepts in Adult Education and Training Routledge Falmer." Taylor \& Francis Group: London and New York, Second Edition available online at http:/gendocs. $\mathrm{ru} /$ docs/23/22969/conv_1/file1. pdf, 2002.

[9] Z. Arif, “Andragogi,” Bandung: Angkasa, 1994. 